\title{
Correction to: A near-shore clastic- carbonate mixing mode in a continental rift basin (early Oligocene, eastern Shijiutuo Uplift, Bohai Bay Basin, China): sedimentology, reservoir characteristics and exploration practice
}

Xiao-Feng Du' ${ }^{1}$, Hao Liu ${ }^{2 *}$, Xiao-Bo Huang ${ }^{1}$, Zhang-Qiang Song ${ }^{1}$, Wei X $\mathrm{u}^{1}$ and Can Zhang ${ }^{1}$

Correction to: Journal of Palaeogeography 9, 25 (2020)

https://doi.org/10.1186/s42501-020-00074-w

Following publication of the original article ( $\mathrm{Du}$ et al. 2020), a minor typo of the author name was found in the Reference,

The incorrect reference is:

Man, T.I. 2014. Facies analysis and sequence stratigraphy of the Cenomanian-Turonian mixed siliciclasticcarbonate sediments in West Sinai, Egypt. Sedimentary Geology 307: 34-46.

The correct reference should be:

Anan, T.I. 2014. Facies analysis and sequence stratigraphy of the Cenomanian-Turonian mixed siliciclasticcarbonate sediments in West Sinai, Egypt. Sedimentary Geology 307: 34-46.

The correct citation in the main text should be (Anan 2014) rather than (Man 2014).

The original paper has been updated.

Author details

'China National Offshore Oil Corporation, Tianjin Branch, Tianjin 300459, China. ${ }^{2}$ School of Ocean Sciences, China University of Geosciences, Beijing 100083, China.

The original article can be found online at https://doi.org/10.1186/s42501020-00074-w.

* Correspondence: Ihcugb@163.com

${ }^{2}$ School of Ocean Sciences, China University of Geosciences, Beijing 100083,

China

Full list of author information is available at the end of the article
Published online: 31 May 2021

Reference

Du, X.F., et al. 2020. A near-shore clastic-carbonate mixing mode in a continental rift basin (early Oligocene, eastern Shijiutuo Uplift, Bohai Bay Basin, China): sedimentology, reservoir characteristics and exploration practice. Journal of Palaeogeography 9: 25. https://doi.org/10.1186/s42 501-020-00074-w.
Springer Open (c) The Author(s). 2021 Open Access This article is licensed under a Creative Commons Attribution 4.0 International License, which permits use, sharing, adaptation, distribution and reproduction in any medium or format, as long as you give appropriate credit to the original author(s) and the source, provide a link to the Creative Commons licence, and indicate if changes were made. The images or other third party material in this article are included in the article's Creative Commons licence, unless indicated otherwise in a credit line to the material. If material is not included in the article's Creative Commons licence and your intended use is not permitted by statutory regulation or exceeds the permitted use, you will need to obtain permission directly from the copyright holder. To view a copy of this licence, visit http://creativecommons.org/licenses/by/4.0/. 